\title{
SIKLÓCSAPÁGY TRIBOLÓGIAI VIZSGÁLATÁNAK SZIMULÁCIÓJA
}

\author{
Papp Szonja \\ hallgató, Miskolci Egyetem, Gép-és Terméktervezési Intézet \\ 3515 Miskolc, Miskolc-Egyetemváros, e-mail: szony97@gmail.com \\ Szávai Szabolcs \\ egyetemi docens, Miskolci Egyetem, Gép- és Terméktervezési Intézet \\ 3515 Miskolc, Miskolc-Egyetemváros, e-mail: szavai.szabolcs@uni-miskolc.hu
}

\begin{abstract}
Absztrakt
Tribológiának nevezzük a kölcsönösen egymásra ható és egymáshoz viszonyitva elmozduló felületek viselkedésének tudományát és technológiáját. A tribológia a szilárd-szilárd, szilárd-folyékony, mozgó szilárd-gáz, folyadék-folyadék és folyadék-gáz határfelületeken lejátszódó jelenségekkel foglalkozik. Tribológiai rendszerek létrejöttekor érintkezési, súrlódási és kopási folyamatok játszódnak le, ezáltal veszteségek alakulnak ki. A cikk tárgya egy siklócsapágy tribológiai szimulációjának elvégzése a meghatározott paraméterek mellett. A vizsgálat során meg kell határozni a rendszerben jelenlévö kenési állapotot, a vizsgált csapágy szilárdsági tulajdonságait, valamint a vizsgálati paramétereket. A betáplált adatokból a szabad felhasználású szoftver futtatásával eredményt kapunk a müködés során fellépö erőkröl, kapcsolatokról, valamint kopási mintákról.
\end{abstract}

Kulcsszavak: tribológia, siklócsapágy, szimuláció, kopásvizsgálat

\begin{abstract}
The scientific method and technique of mutually interacting and moving surface's behavior is called tribology. It deals with the interaction of solid with solid, solid with liquid, moving solid with gas, liquid with liquid and liquid with gas boundary surfaces. Contact, friction and wear happens in tribology systems, which can cause losses. The subject of this article is to perform tribological simulation of a plain bearing as a function of the specified parameters. During the examination, we have to define the following: the condition of the lubrication, the properties of the examined bearing, and the parameters of the examination. From the input data the free software can predict the operating forces and wear patterns.
\end{abstract}

Keywords: trybology, plain bearing, simulation, wear test

\section{Bevezetés}

A tribológiai rendszerek olyan mechanikai rendszerek, amelyekben érintkezési, súrlódási és kopási folyamatok játszódnak le, így veszteségek alakulnak ki. Tribológiához kapcsolódó alkalmazott tudományok a tribotechnika, a tribofizika, a tribokémia a tribokutatás és a tribológiai igénybevétel. A tribotechnika a tribológiai kutatások eredményeinek gyakorlati alkalmazása. Tribofizikának nevezzük azon fizikai jelenségek összességét, amelyek az egymáshoz viszonyított elmozduláskor végbemennek. Ilyen jelenségek például a súrlódás, a mechanikai kopás, a rugalmas és a maradó alakváltozás, a termikus jelenségek, illetve a kenőanyagban végbemenő fizikai folyamatok. Tribokémia alatt azon kémiai 
változásokat értjük, amelyek a fémes felületen vagy a kenőanyagban a súrlódás és a környezet hatására végbemennek, pl.: oxidáció, adalékok kémiai hatása (szulfid, foszfát vagy oxid fémek, bevonatok képződése). A tribokutatás a jellemző nagyság kölcsönös függőségének és a fennálló törvényszerüségek méréstechnikai meghatározása, a tribológiai igénybevétel pedig a relatív mozgás és a felületek kölcsönhatását tanulmányozza. [1]

\section{Tribológiai rendszer}

A rendszer leírható a fekete doboz módszerrel, melynek során kijelölünk egy rendszerhatárt, vagyis a rendszert elkülönítjük a környezettöl. Ezután megállapítjuk a be- és kimenő mennyiségeket, majd ezen mennyiségek közötti összefüggéseket. A rendszer szerkezeti leírásánál fontos a rendszerelemek azonosítása, az elemek közötti kapcsolatok megállapítása, valamint az elemek fontosabb paramétereinek meghatározása. Különböző tulajdonságokkal jellemezhető a rendszer, mint például geometriai- és anyagjellemzők.

$\mathrm{Az}$ állandó változás a tribológiai rendszer fontos jellemzője, mivel a keletkező veszteségek megváltoztatják a rendszer viselkedését. Ez az oka annak, hogy nem elegendő a be- és kimenő mennyiségek közötti kapcsolatot vizsgálni. Szükséges a tribológiai hatásokra kialakuló rendszerszerkezet változásainak és azok rendszermüködésre gyakorolt hatásainak a tanulmányozása.

A rendszer részei egymással mozgó kapcsolatban vannak. Fő részei a két egymáshoz viszonyítva elmozduló felület és azok környezete (1. ábra). Az alapanyag, az összetevők kialakítása, a köztes anyagok, a környezeti befolyások és az alkalmazási feltételek határozzák meg a kopás jellegét, lefolyását, illetve a mértékét. [1]

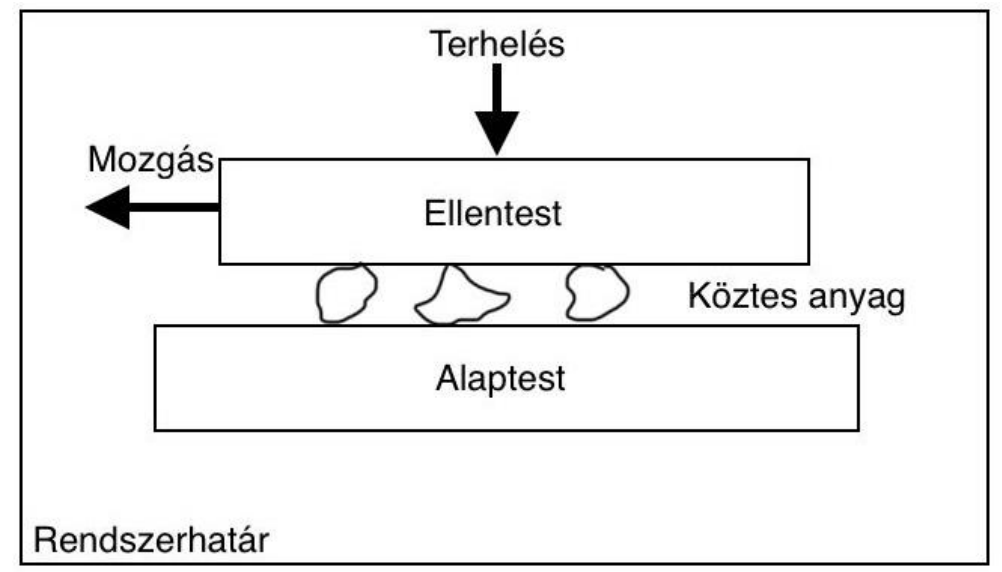

1. ábra. A tribológiai rendszer sematikus ábrája [1]

\section{Súrlódás}

A súrlódás az egymáshoz képest elmozduló anyag részecskéi között fellépő mozgásgátló hatás. A súrlódási erő ellentétes értelmü az elmozdulással [1].

A Coulomb-Amonton súrlódási tényező a súrlódás dimenzió nélküli viszonyszáma, ami két test egymásra gyakorolt hatásának az érintősík irányába eső, elmozdulással szembeni erőkomponens fajlagos értéke [3]. 


$$
\mu=\frac{F_{s}}{F_{n}}
$$

ahol:

- Fs a súrlódási erö,

- Fn a normál erő.

\subsection{A súrlódási tényezőt befolyásoló hatások}

- Anyagminőség: anyag belső szerkezetét, hővezetését, a súrlódó felületek rugalmasságát, illetve merevségét értjük alatta

- Felületi minőség: felület érdességét, súrlódó felületek állapotát jelenti

- Igénybevételi körülmények: csúszás sebességének, terhelés nagyságának, üzemi hőmérséklet, valamint a súrlódó pár illeszkedésének meghatározása

A súrlódás két fő csoportra osztható. Belső súrlódás az anyag részecskéinek relatív elmozdulásánál lép fel, külső súrlódás pedig a szilárd testek érintkező felületein. Utóbbinál három különböző esetet különböztethetünk meg:

- Csúszó súrlódás: ebben az eseten az egyik test irányban csúszik a másik test felületén

- Forgási súrlódás: ilyenkor az egymással érintkező felületek egy adott forgástengely körül körpályát írnak le

- Gördülő súrlódás: ebben az esetben az egymáson legördülő forgástest mozgását egy erő nyomatéka okozza

\section{Kopás}

A felszíni károsodás egyik legjellemzőbb formája a kopás. Kopás alatt az egymással súrlódó kapcsolatban lévő felületek anyagi részecskéinek leválását és ezáltal a felület geometriájának visszafordíthatatlan megváltozását értjük. A kopási folyamatot két csoportba lehet osztani: enyhe és intenzív. Ezt csak azok a vizsgálatok mutatják ki, ahol azt találták, hogy növelve a normál terhelést, vagy térfogati hőmérsékletet, vagy a relatív csúszási sebességet van egy olyan határ, ahol a kopási együttható hirtelen, nem lineáris módon megugrik.

Enyhe kopás tartományában relatíve sima felület keletkezik, a keletkező törmelék-átmérő kisebb, mint $100 \mathrm{~nm}$. Az ilyen kopás miatt nagy kontaktellenállás jön létre.

Ezzel szemben az intenzív kopás tartományában a keletkező felület durva, mélyen barázdált a kiinduló állapothoz képest. Nagy törmelék-átmérő, akár 0,01-es átmérővel. Tiszta fémes kapcsolat a felületek között, így alacsony elektromos kontaktellenállás. Mérnöki szempontból elmondható, hogy míg a enyhe kopás megengedhető, addig az intenzív kopás kerülendő folyamat. Ezért fontos tudni, hol van a két különböző típusú folyamatot elválasztó határ, illetve az üzem során becsülni a kopási együtthatót, ezáltal beazonosítani, hogy az intenzív határtól milyen messze áll folyamat.

A kopási folyamat jellemzésére használható az általános kopásdiagram (2. ábra), mely három egymástól különböző szakaszra bontható:

I bejáratási szakasz: degresszív

II állandósult kopás: kvázi-lineáris

III túlkopás (berágódás): progresszív 


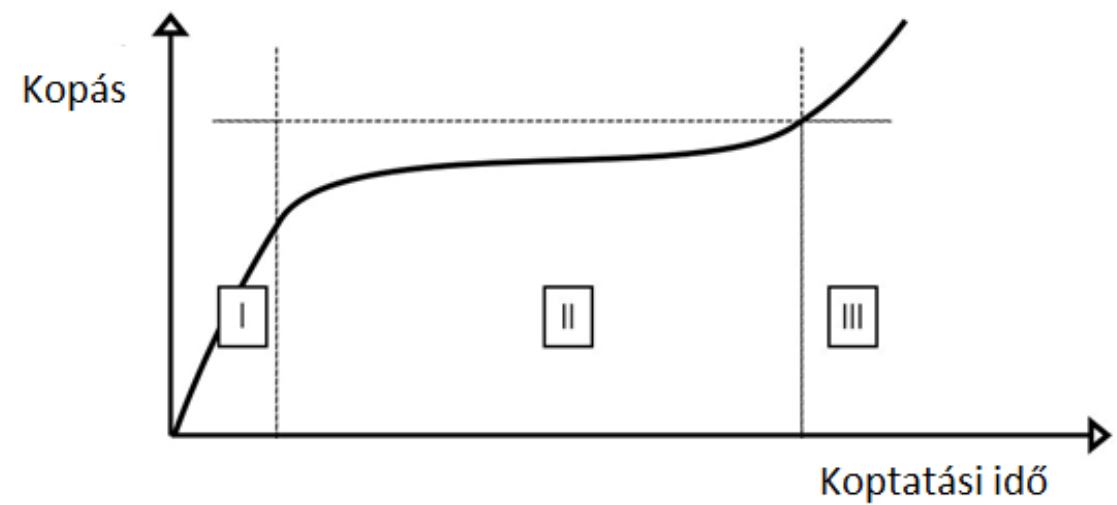

2. ábra. Jellegzetes kopásgörbe [1]

\section{Csapágyak szerepe}

A csapágyak olyan gépelemek, amelyek tengelyek, forgó alkatrészek alátámasztásául szolgálnak, úgy, hogy a forgó mozgást minél kisebb ellenállás mellett, minél pontosabb vezetéssel biztosítsák. A csapágyba illeszkedik a tengelycsap. A csapágyaknak általában különböző terhelésekből adódó nagy erőket kell felvenniük, melyek származhatnak a forgó alkatrész súlyából, a kiegyensúlyozatlanságból származó forgó és alternáló tömegerőkből, vagy akár a gép müködése folyamán fellépő más hatásokból is [4].

A csapágyak csoportosítása történhet müködési elv és a terhelés iránya szerint. Terhelés iránya alapján megkülönböztetünk:

- Axiális (3. ábra),

- Radiális (4. ábra),

- Axiális és Radiális erők felvételére alkalmas csapágyakat.

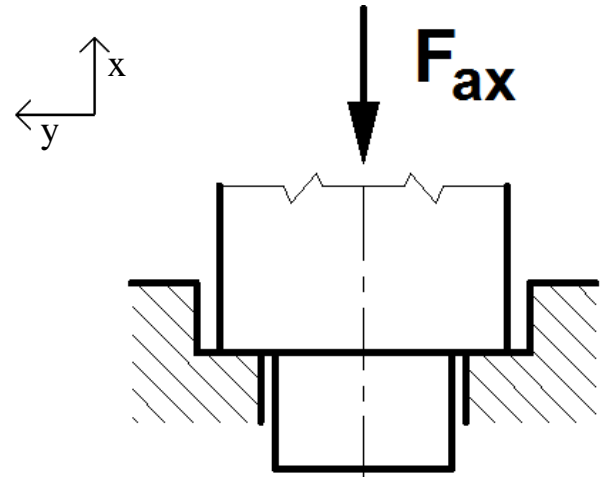

3. ábra. Axiális terhelés

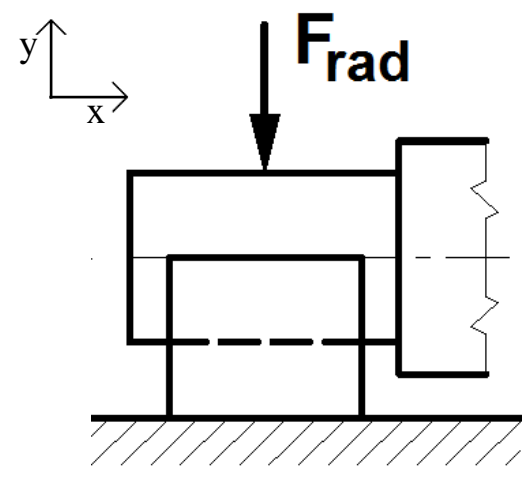

4. ábra. Radiális terhelés

Müködési elv szerint a csapágyak típusai lehetnek:

- Gördülőcsapágy

- Mágneses elven múködő csapágy

- Rugalmas csapágy

- Siklócsapágy 


\subsection{Gördülő́csapágy}

A gördülőcsapágyaknak két fő csoportját különböztetjük meg, a golyóscsapágyakat, valamint a görgőscsapágyakat, melyeknek terhelhetősége nagyobb. A gördülőcsapágyak fő jellemzői, hogy a csapágy erőfelvétele gördülő testeken keresztül megy végbe. Nagy előnye, hogy a gördülési súrlódás jelentősen kisebb ellenállással bír, mint a csúszási súrlódás.

\subsection{Mágneses elven müködő csapágyak}

A mágneses elven müködő csapágyak lényege, hogy a csap és a csapágy között létrejövő rést egy vezérelt elektromágnes biztosítja, melynek pozitív következményeképpen a csap és csapágy között nincs fizikai kontaktus, ezáltal csökkentve minimálisra a súrlódási erőt, valamint kivárva a mechanikai kopás jelenlétét. A mágneses csapágyak képviselik a legnagyobb sebességet elbíró csapágyakat, ugyanis nincs maximálisan megengedett relatív sebességük.

\subsection{Rugalmas csapágyak}

A rugalmas csapágyak nem alkalmasak forgó mozgás megvezetésére. Feladatuk kis szögelfordulás biztosítása kis ellenálással egy rugalmas elem közbeiktatásával. Nagyon alacsony és kiszámítható súrlódási erőt biztosítanak, és egyszerüségük miatt meglehetősen olcsók.

\subsection{Siklócsapágyak}

A siklócsapágyak, vagy más néven csúszócsapágyak a legegyszerúbb csapágykialakítással rendelkeznek. A csap és a csapágy között csúszó súrlódás jön létre. Egyszerü szerkezetüknek köszönhetően rendkívül gazdaságos a használatuk, valamint könnyen javíthatók. A gördülőcsapágyakhoz képest egy sokkal simább, csendesebb futást biztosítanak. Nagy hátrányuk azonban az elemek között fellépő nagy súrlódási erő és kopás, ami miatt fontos az optimális csapágyanyag megválasztása és a megfelelő kenés biztosítása.

\section{Siklócsapágyak optimális anyagösszetételei}

A siklócsapágyakat olyan anyagokból kell elkészíteni, melyek képesek nagy eröket felvenni, kicsi a súrlódási együtthatójuk, ellenállóak a megemelkedett hőmérséklettel szemben és korrózióállók. Ezen szempontok figyelembevéve kell kiválasztani a megfelelő csapágy anyagot. Felhasználási területtől függően a legkülönfélébb anyagokból választhatunk [5].

\section{1. $\quad$ Bi - material}

A bi - material, vagyis két anyagból álló csapágyaknál a külső, nagy terheléseket felvevő felületet fémből, míg a belső, csappal érintkező felületet müanyagból készítik. Az ellenálló külső fém héj képes nagyobb terheléseket is felvenni, míg a kevésbé strapabíró, belső müanyag hüvely kisebb súrlódásának köszönhetően simább járást és kisebb kopást eredményez.

\subsection{Fehérfém}

Rendkívül előnyös tulajdonságokkal rendelkeznek a lágy, szárazon is jó súrlódási jellemzőkkel bíró fehérfémből készült csapágyperselyek. Ezek a fehérfém perselyek készülhetnek ónból, ólomból vagy akár antimon ötvözetéböl. 


\subsection{Grafit}

A grafit szilárd kenőanyagként viselkedik, ebből következtethetően meglehetősen jó választás siklócsapágy anyagának. Vegyítetlen formában akár nedves körülmények melletti használatra is alkalmas.

\subsection{Plasztik}

Manapság a mủanyag csapágyak meglehetősen nagy népszerüségnek örvendenek, mivel nem igényelnek kenőanyagot, nem korrodálódnak, kicsi a tömegük és nem igényelnek karbantartást. Azonban hátrányaik is akadnak. A hőtágulási együttható változása nem lineáris, valamint nagy tartományban mozog, ezért tervezésnél bonyolult vele számolni. A nem rendeltetésszerü használatból adódóan rendkívül gyorsan melegednek.

\section{Siklócsapágy kopásanalízise}

A siklócsapágyak felületei között felléphet határréteg-súrlódás, vegyes súrlódás, folyadéksúrlódás, de alapvetően folyadék-(hidrodinamikus) súrlódás állapotára tervezik a siklócsapágyakat. Az egyes súrlódási állapotok fellépésének lehetőségét a Stribeck görbe (5. ábra) segítségével lehet megállapítani a jellemzö üzemi paraméterekböl, mint a kontaktfelületen ébredő nyomás, a tengely szögsebessége és a kenőanyag dinamikus viszkozitása.

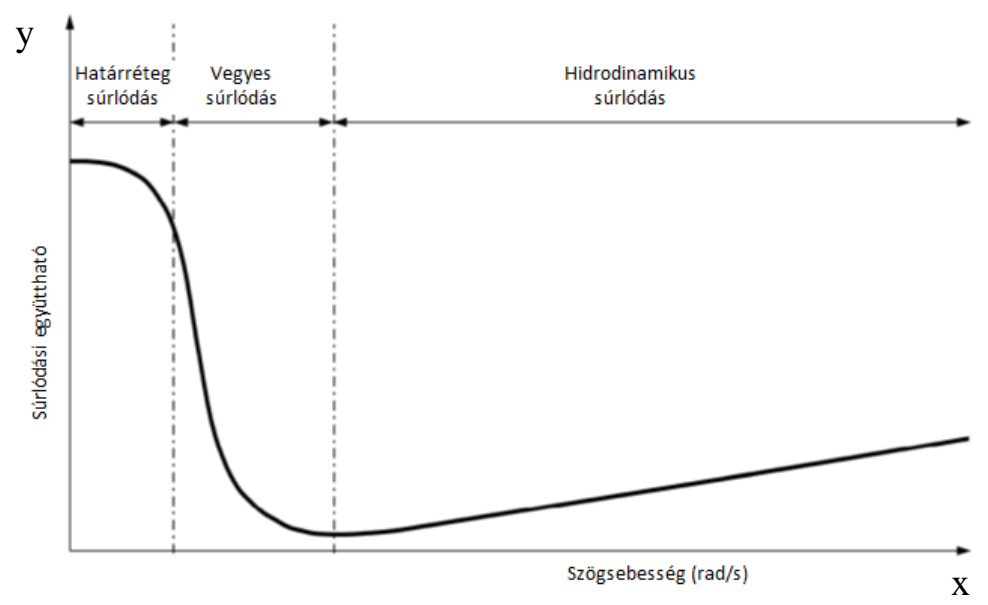

\section{5. ábra. Stribeck görbe}

A hidrodinamikus kenési állapotban lévő siklócsapágy esetére a kontaktfelületi nyomás eloszlását mutatja be a 6. ábra. A hidrodinamikus (folyadék) kenési állapotban a felületek a felszín érdességénél nagyobb mértékben van elválasztva egymástól, így a kenőfilm tökéletesen elválasztja kontaktfelületeket, ami az adhéziós kopást teljes mértékben meggátolja. A kenőfilmbe bejutó porszemcsék okozhatnak csak abrazív kopást. A hidrodinamikus kenés mellett megfelelő terhelésnél és magas vagy ultra magas ciklusszámnál következhet csak be kontaktfelületi kifáradás.

Álló helyzetben a nyugalmi állapotot veszi fel tengely és a kenőanyag a siklócsapágyon belül [6]. Indításkor egy nagyon rövid időtartamra lép fel az indulási állapot. Ebben az állapotban a tengely elöször gördül a csapágyfalon, ezáltal jut abba a pozícióba, ami a 7. ábrán látható. 


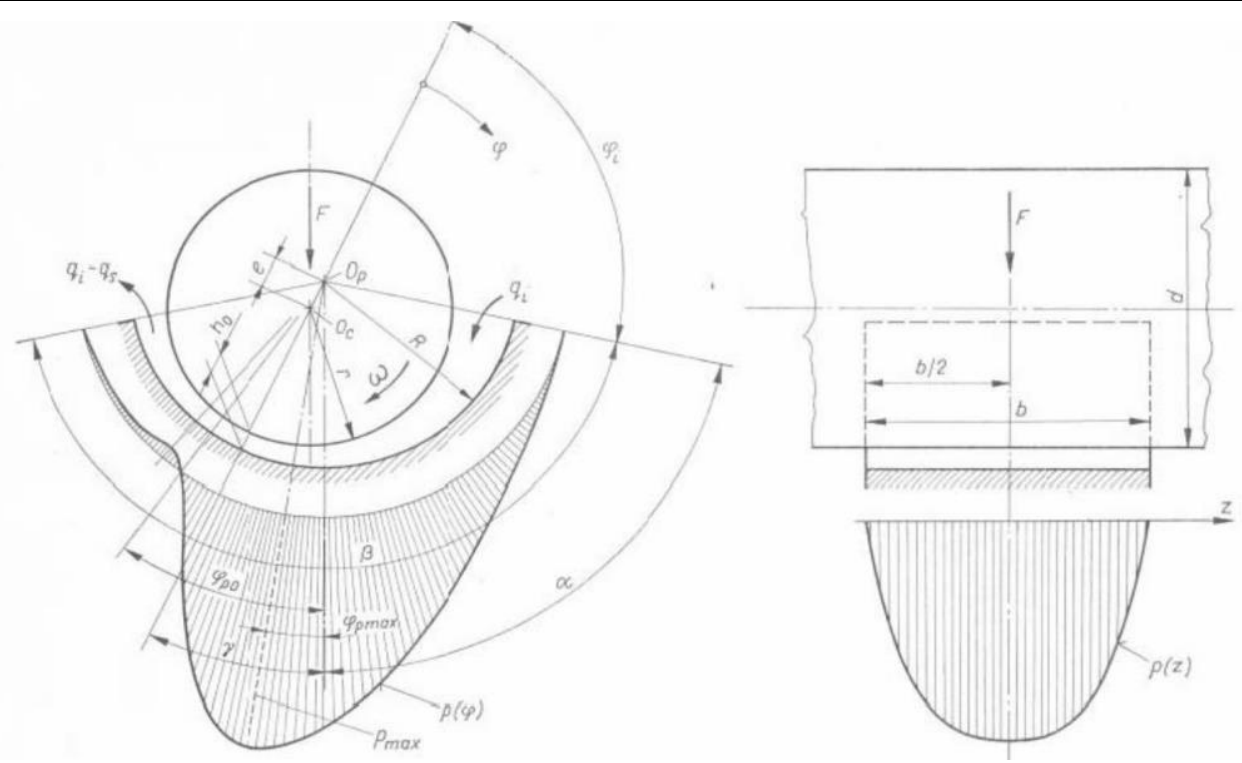

6. ábra. Hidrodinamikus nyomás eloszlása a siklócsapágy csúszó felületén.

Ez a mozgás fokozatosan átvált csúszásba, amivel párhuzamosan felépül a hidrodinamikus nyomás, és fokozatosan kezdi a tengely megközelíteni az üzemi állapotot. Az üzemi állapotban megközelíti a rendszer az elaszto-hidrodinamikus kenési állapotot és felveszi az állandósult állapotú pozícióját, amint azt a 7. ábra is mutatja.

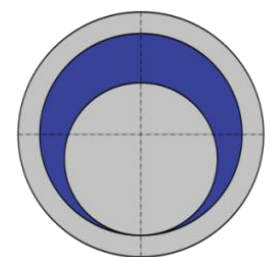

$\omega_{0}=0$

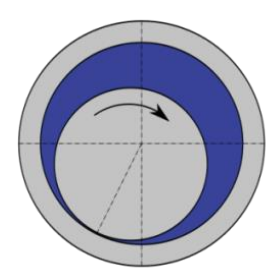

$\omega_{>}>\omega_{1}$

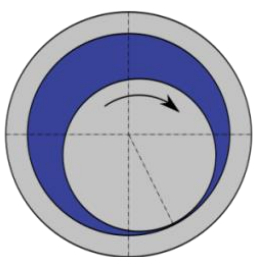

$\omega_{1}>0$

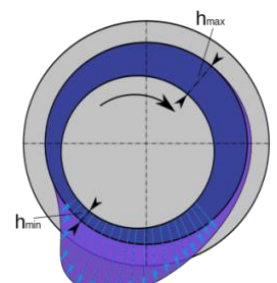

$\omega_{3}>\omega_{2}$

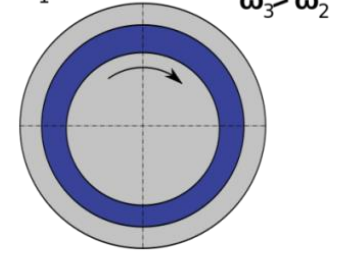

$\omega \rightarrow \infty$

7. ábra. A siklócsapágy jellemzö állapotai az életciklusa során. 
A leállás során az indulási állapothoz képest egy hosszabb időtartamban a tengely fokozatosan, monoton módon megközelíti a nyugalmi állapotot, és végül elfoglalja az ehhez tartozó pozíciót, amikor a forgása leáll [7].

\section{Tribológiai szimuláció}

A kopás szimulációját a Tribology Simulator nevü szoftver segítségével végeztük el. A szoftver a leggyakrabban előforduló tribológiai érintkezési feladat (2, egymáshoz képest relatív mozgásban lévő, érdes felület érintkezése) szimulációjára alkalmas. Maga a szoftver egy ingyenes, Matlab alapú szimulációs szoftver, ami alkalmas az általános tribológiai folyamatok modellezése [8]. A felület mikrogeometriáján kívül azok mikrogeometriáját vagy nanogeometriáját (érdesség) is figyelembe lehet venni. A szoftver alkalmas még Stribeck görbe szimulációjára, érintkezési hőmérsékelt számítására is.

A szimulátor fő funkciója a vegyes kenési körülmények közt érintkezö kontaktfelületek között fellépő súrlódás számítása, amikor a terhelést részben a kenőanyag, részben pedig a közvetlenül érintkező felületek veszik fel. A számítás alapja Johnson terheléseloszlás elmélete. A szimulációban két határesetet vizsgál: a száraz érintkezést, amikor a terhelés egészét a kapcsolódó felületek veszik fel, illetve a folyadéksúrlódási állapotot, amikor a terhelést a kenőanyag veszi fel.

\section{Eredmények kiértékelése}

A szimuláció során az alábbi eseteket vizsgáltuk meg, illetve az alábbi paramétereket alkalmaztuk:

Vizsgálati hömérsékletek: $\quad-20^{\circ} \mathrm{C}$

$$
-80^{\circ} \mathrm{C}
$$

Vizsgált terhelések: - $10 \mathrm{~N}$

$$
\begin{aligned}
& -50 \mathrm{~N} \\
& -100 \mathrm{~N}
\end{aligned}
$$$$
-200 \mathrm{~N}
$$

Sebesség: $0,628 \mathrm{~m} / \mathrm{s}$

\section{Csapágy adatai}

Anyaga: EK2230

Anyagtulajdonságok különböző hőmérsékleteken:

$$
\begin{aligned}
& 20^{\circ} \mathbf{C}-\mathrm{k}=5.45 \mathrm{E}-07 \mathrm{~mm}^{3} / \mathrm{Nm} \\
&-\mathrm{H}=240(\mathrm{HBN}) \\
&-\mathrm{K}=1.308 \mathrm{E}-4 \\
& 80^{\circ} \mathbf{C} \quad-\mathrm{k}=2.475 \mathrm{E}-07 \mathrm{~mm}^{3} / \mathrm{Nm} \\
&-\mathrm{H}=240(\mathrm{HBN}) \\
&-\mathrm{K}=1.308 \mathrm{E}-4
\end{aligned}
$$

\section{Tengely adatai}

Anyaga: X46Cr13

Anyagtulajdonságok különböző hőmérsékleteken:

$$
\begin{aligned}
20^{\circ} \mathbf{C} & -\mathrm{k}=1 \mathrm{E}-10 \mathrm{~mm}^{3} / \mathrm{Nm} \\
& -\mathrm{H}=240(\mathrm{HBN}) \\
& -\mathrm{K}=2.4 \mathrm{E}-8 \\
-80^{\circ} \mathbf{C} & -\mathrm{k}=1 \mathrm{E}-10 \mathrm{~mm}^{3} / \mathrm{Nm} \\
& -\mathrm{H}=240(\mathrm{HBN}) \\
& -\mathrm{K}=2.4 \mathrm{E}-8
\end{aligned}
$$


Az alábbiakban láthatóak az Tribology Simulatorban kapott eredmények összesítései diagram formátumban:
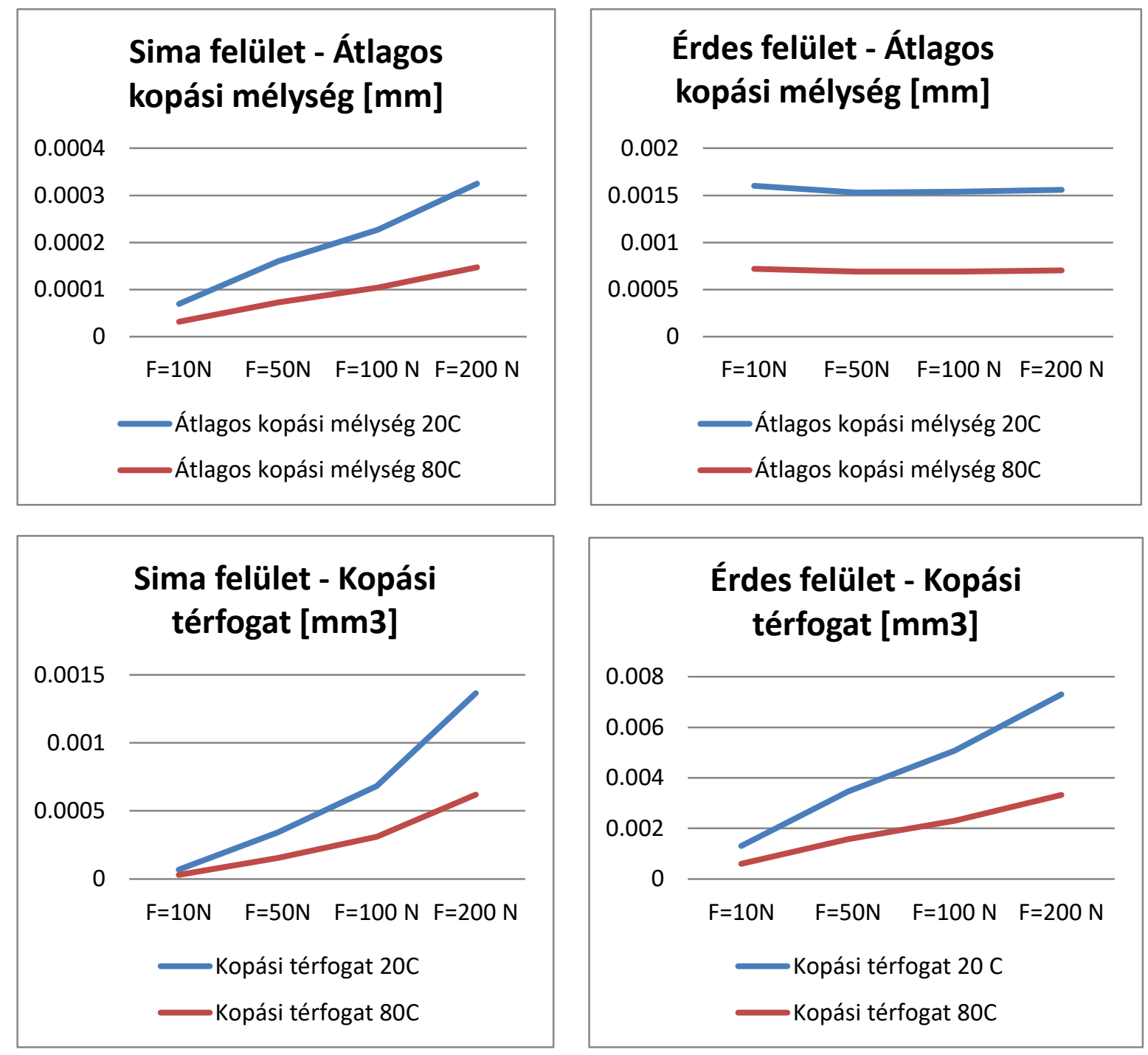

8. ábra. A kapott eredmények összesitései

Az eredmények alapján látható, hogy a terhelés növelésével a kopási folyamat gyorsul, a diagram 100 N-nál megugró növekedést tapasztalhatunk. A különböző terhelések mellett tesztelt csapágyak felületét fontos vizsgálni a kopás nyomok elemzésével, hogy megbizonyosodjuk arról, hogy a károsodási mechanizmus ugyanaz a különböző terhelések mellett. Az eddigi szimulációs eredmények alapján a hőmérséklet $80^{\circ} \mathrm{C}$-ra növelése lassítja a kopás folyamatát. 


\section{Köszönetnyilvánítás}

A cikkben ismertetett kutató munka az EFOP-3.6.1-16-2016-00011 jelü „Fiatalodó és Megújuló Egyetem - Innovatív Tudásváros - a Miskolci Egyetem intelligens szakosodást szolgáló intézményi fejlesztése" projekt részeként - a Széchenyi 2020 keretében - az Európai Unió támogatásával, az Európai Szociális Alap társfinanszírozásával valósul meg.

\section{Irodalom}

[1] Jenei, I., Ladányi, G.: Kenésgazdálkodás, 2013.

[2] Előd, A.: Géptervezés I., Budapest, 1994.

[3] BME Jármügyártás és -javítás Tanszék: Károsodás (letöltés ideje: 2019.11.29.)

[4] Pattantyús, Á.: Gépész- és Villamosmérnökök Kézikönyve, 2. kötet. Müszaki Könyvkiadó, Budapest, 1961.

[5] Dean RR, Evans CJ: Plain bearing materials, 2003.

[6] Mokthar, M. O. A., Howarth, R. B., Davies, P. B.: The behavior of plain hydrodynamic journal bearings during starting and stopping, ASLE Trans, Vol. 30(3), p.183-90, 1977. https://doi.org/10.1080/05698197708982832

[7] Williams, J. A.: Engineering Tribology, 1994

[8] Tribology Simulator User Manual, www.tribonet.org, 2018. 